\title{
FIELD EVALUATION OF NON-SYNTHETIC INSECTICIDES FOR THE MANAGEMENT OF INSECT PESTS OF OKRA ABELMOSCHUS ESCULENTUS (L.) MOENCH IN GHANA
}

\author{
D. Obeng-Ofori and J. Sackey
}

Department of Crop Science, Faculty of Agriculture, PO Box 44

University of Ghana, Legon, Ghana. E-mail: dobeng@ug.edu.gh

\begin{abstract}
In a two-year study, aqueous seed extracts of the neem tree Azadirachta indica A. Juss (Meliaceae) and Bacillus thurigiensis (Bt) were evaluated in the field for the management of pests of okra, Abelmoschus esculentus (L.) Moench. The aqueous neem seed extracts were applied at the rate of 30, 50, 75 and $100 \mathrm{~g} / 1$ and B.thurigiensis was applied at the rate $1.0 \mathrm{~g} / 1$ of water. Actellic $25 \mathrm{EC}$, a synthetic insecticide, was applied at the rate of $2 \mathrm{ml} / 1$ as standard check. Arthropod fauna on okra were sampled using traps, sweep nets, aspirators and handpicking. The nature of damage caused to the stems, leaves, flowers and fruit was assessed by visual observation. The major insect pests of okra collected were Podagrica uniformis Jac, Aphis gossypii Glov, Sylepta derogata (F.), Spodoptera litoralis Boisd, Prodenia litura (F.), Dysdercus superstitiosus (F.), Epilachna similis (F.), Bemisia tabaci (Genn.) and Zonocerus variegatus (F.). These pests were observed attacking mainly the leaves of okra. Some of the minor pests identified were Lagria villosa (F.), L. cuprina Thoms, Mylabris temporalis Wellni, M. trifasciata (Thumb.), Lapidognatha sp and Empoasca devastans (D.). Actellic, neem seed extract and Bt significantly reduced the population and damage caused by the major insect pests of okra recorded at Legon, Ghana compared to the untreated. Actellic and aqueous neem seed extracts were equally effective against the pests of okra and caused a significant reduction in insect damage to the leaves, flowers and fruit of the crop. There were no significant differences among the different dosages of neem seed extract on all the parameters assessed, with the exception of the final fruit yield. Actellic, neem extracts or Bt produced higher yield of marketable fruit of okra than untreated plants. Neem seed extract applied at the rate of $30 \mathrm{~g} / \mathrm{l}$ of water to okra plants produced lower fruit yield than those treated with $50 \mathrm{~g}$ or more. Aqueous neem seed extracts and $\mathrm{Bt}$ can be used effectively by farmers as a component of integrated management of pests of okra in Ghana.
\end{abstract}

Key words/phrases: Bacillus thurigiensis (Bt), insect pests, neem seed extract, non-synthetic insecticides, okra

\section{INTRODUCTION}

Okra, Abelmoschus esculentus (L.) Moench (Malvaceae) is one of the major vegetable crops grown in West Africa. It is a native of tropical Africa, but now widespread throughout the tropics (Norman, 1992; Sinnadurai, 1992). It is known in various names as okra, okro, bhindee, lady's fingers and quinbambo (Norman, 1992). Okra is mainly cultivated for its green immature fruits, which are used as vegetable. It can be preserved by freezing or canning as is done in the United States of America (Spivey et al., 1957). The fresh leaves can be used as spinach in soups while the seeds are said to be good sources of oil (Oyolu, 1977). Okra fruit have high nutritive value and therefore play very important role in the diet of many Ghanaians (Norman, 1992). Apart from its nutritive value, it is also a major source of income for many vegetable growers in Ghana and other parts of the world.

It was reported that okra may produce up to 3-6 tonnes/ha of green pods with approximately 4-6 fruits/plant, over a harvesting period of 30-40 days (Sinnadurai, 1992). In Ghana, however, the number of fruits per plant are usually more than 20 and the harvesting period extends for over 60 days if there is adequate rainfall (Norman, 1992). The potential yield of okra in the magnitude of 2,559-6,936.8 fruit/ha is not realised due to a number of constraints. Among the major problems that affect okra production in Ghana are leaf curl and okra mosaic diseases caused by viruses, brown leaf mould caused by Cercospora abelmoschi and black leaf mould disease caused by Irenopsis sp (Norman, 1992).

Between 1910 and 1960 ten important insect pests of okra were recorded in Ghana (Forsyth, 1966), while in the Sudan as many as 36 insect pests were found permanently associated with the crop (Schmutterer, 1969). In India, 16 insect species were recorded attacking okra (Butani and Verms, 1976). These insects cause serious economic loss by boring holes into the leaves and reducing the photosynthetic ability of the leaves. Some of the insects pierce and suck sap from the plants. They may also bore holes into the fruit and reduce their quality. The holes also provide penetration sites for the entry of plant pathogens (Pursglove, 1972).

In the control of insect pests of okra, many farmers rely on the use of synthetic chemicals such 
as actellic 25 EC (pirimiphos-methyl) and heptachlor (Murthy, 1959), thiometon (David, 1964), which are applied on weekly calendar schedules. More often, farmers use chemicals recommended for cotton and cocoa on vegetables. These synthetic chemicals are harmful to the environment and their chemical residue may be found in the fruit. The chemicals are also dangerous to the health of the users and can kill other non-targeted animals. Indeed, the continued use of high doses of synthetic insecticides, at very high costs, had completely eliminated the indigenous natural enemies and other beneficials that would otherwise normally keep pest populations under control (Youdeowei, 2000). Many insects have also developed resistance to these chemicals (Youdeowei, 2000). Synthetic insecticides are also expensive and many resourcepoor farmers cannot afford to buy the recommended chemicals to protect their crops against pest infestation. There is therefore the need to develop alternative methods of control that are relatively cheap and less destructive to environment and the end user.

Several plant species have been reported to have insecticidal properties (Golob and Webley, 1980; Schmutterer, 1985). Much work has been done on the neem tree Azadirachta indica A. Juss which has been found to be effective against several species of insect pests of major crops including vegetables (Schmutterer, 1990; Obeng-Ofori and Akuamoah, 1998). The neem tree contains several biologically active compounds but Azadirachtin is the main component (Schmutterer, 1990). Almost every part of the plant contains the compound, however, the seeds are the richest source. Neem products have antifeedant, repellent, growth-inhibiting and toxic properties against insects (Schmutterer, 1985).

Bacillus thuringiensis is a spore-forming bacterium that produces a crystal of toxic protein (deltaendotoxin) (Hall et al., 1977). The toxin is biologically active against the larvae of several species of insects, particularly moths and flies (Garcia and Goldberg, 1977). Two varieties of B. thuringiensis are currently widely produced and marketed under different trade names such as Bactospeine, Bactimos, Dipel, Biobit and Thuricide (Hall et al., 1977).

The widespread use of different types of plant materials by medium to small-scale farmers in the developing countries to protect crops against pest infestation and the need to develop bio-rational control strategies have stimulated active research on the efficacy, effective application, economics of control and the suitability of non-synthetic insecticides for pest control. This study evaluated the effectiveness of neem seed extracts and $B$. thuringiensis for the control of insect pests of okra in Ghana.

\section{MATERIALS AND METHODS}

\section{Land preparation and planting}

The experiments were carried out at the University of Ghana farm, Legon in the major (April-July) and minor (September-December) planting seasons of 1999 and 2000. Thus, two cropping activities with the same treatments were carried out in each year. The area has a mean annual rainfall of $880.75 \mathrm{~mm}$, mean temperature of $28.5^{\circ} \mathrm{C}$ and relative humidity of $81 \%$. The local Labadi Dwarf okra variety was used in all the experiments. The seeds were soaked in water overnight to ensure uniform germination before planting them directly into the soil using a dibber to the depth of $1.2-1.5 \mathrm{~cm}$ at the rate of four seeds per hill and planting distance of $50 \mathrm{~cm} \times 80$ $\mathrm{cm}$. The stands were thinned to two plants after four weeks.

\section{Cultural practices}

The plots were fertilized with N.P.K. (15:15:15) by band placement at the rate of $300 \mathrm{~kg} / \mathrm{ha}$, three days before planting of okra seeds. Six weeks after planting, sulphate of ammonia was broadcasted at the rate of $200 \mathrm{~kg} /$ ha followed by heavy watering. Weeds were controlled manually by hoeing and the plants were watered when necessary.

\section{Extraction of neem seed}

Matured neem seeds were collected from neem trees at Legon campus and in the 37 Military Hospital area and dried for few days under shade. The seeds were milled into powder and then soaked in water and left to stand overnight. The solution was filtered using Whatman's. No. 42 filter paper and the filtrate were applied at the rate of 30,50, 75 and $100 \mathrm{~g}$ of neem seed/litre of water.

\section{Application of products}

The experiments were laid out in Randomised Complete Block Design with four replications. There were seven treatments namely; water only as check, Actellic 25 EC applied at the rate of 2 $\mathrm{ml} /$ litre of water, neem seed extract at $30,50,75$ and $100 \mathrm{~g}$ of neem seed/litre of water and $\mathrm{Bt}$ at the rate of $1 \mathrm{~g} /$ litre of water. The products were applied using a knapsack sprayer when the plants were two weeks old and then after every fortnight until maturity. In total each treatment was applied five times. Each treatment plot had a size of $11.6 \mathrm{~m}^{2}$ and the spacing between and within rows were 0.8 $\mathrm{m}$ and $0.5 \mathrm{~m}$, respectively. 


\section{Sampling of insects on okra}

Five tagged okra plants per treatment were observed daily, and insects found on them were collected using aspirators, sweep nets, yellow sticky traps or by hand-picking where appropriate. The yellow sticky traps were placed at both ends of each plot and inspected daily. Sampling of insects started two weeks after planting. This was done a day before spraying, one day after spraying and five days thereafter. All insects collected were sent to the entomology laboratory of the Crop Science Department for identification. Thereafter, the insects were prepared and mounted in insect boxes. Where immature insects were collected they were reared to adult stage in the laboratory with temperature of $26 \pm 2{ }^{\circ} \mathrm{C}$ and $70-80 \%$ relative humidity. The larvae were reared in glass jars and fresh pieces of okra leaves were supplied to them daily. The pupae were kept in Petri dishes containing moist cotton wool until emergence. The feeding activity and the nature of damage caused by the various insects was determined by visual observation. The numbers of insects collected on okra plants treated with the various products at different sampling periods using the different sampling techniques were pooled and the mean per plot was calculated.

\section{Leaf and fruit damage}

The feeding on okra leaves and fruit by the various insect pests was quantified to determine the effect of the different products on the feeding activity of the pests. For leaf damage, the number of holes (feeding punctures) with 0.5-1.0 mm diameter on the five tagged okra plants were recorded. All the leaves of the tagged plants were examined and those with and without feeding punctures were recorded and percentage leaf damage was then calculated. On maturity the fruit were harvested at weekly intervals over one month period and separated into damaged and undamaged depending on the presence or absence of feeding punctures on the fruit. The percentage fruit damage was calculated on the total number of fruit harvested.

\section{Fruit yield}

On maturity the fruit were harvested from all the plants in the plot at weekly intervals over one month period and were sorted out into marketable and unmarketable fruit. Fruit yield was calculated based on mean yield of marketable fruit per plant, spacing and plot size.

\section{Analysis of data}

All count data on the major insect pests and yield were transformed using the square root transformation and data on percentage leaf and fruit damage were transformed using arcsine before analysis of variance was performed. Where significant differences were observed, means were separated using the Least Significance Difference (LSD).

\section{RESULTS}

\section{Insect fauna on okra}

The species of insects collected on untreated okra plants belonged to five orders namely, Coleoptera, Heteroptera, Homoptera, Lepidoptera and Orthoptera (Table 1). It was observed that the population densities of the various insect pests, particularly the aphids, grasshoppers and caterpillars were higher during the minor season (September-December) than during the major season (April-July). Five species of beetles were found feeding on leaves of okra. The cotton flea beetles, Podagrica uniforms (Jac) (Chrysomelidae) were very destructive to the leaves, flowers and fruit, but the damage was severe on the leaves. They fed on both the upper and the undersides of the leaves and bored numerous holes into them. Two species of Lagria were found. Lagria villosa (F) and L. cuprina (Thoms). These were observed feeding on the upper sides of leaves. Their numbers were, however, low and did not cause any appreciable damage.

The blister beetles, Mylabris abdominalis Thumb, $M$. temporalis (Wellni), and M. trifaciata Thumb occurred mainly during the flowering stage. Their numbers, however, reduced considerably when a lot of fruits had formed. The three species were all observed feeding on the flowers but $M$. trifaciata fed also on the green fruits. Two species of Chellomonos occurred regularly depending on the presence of aphids on the leaves. These were $C$. lunata (F.) and C. vicina Muls and they fed on aphids. Scolytid beetles, Labidognatha species were found in small colonies when the plants were ten weeks old. They fed on the upper sides of leaves but the damage caused was not serious.

The adults and larvae of Epilachna similis (L.) were very destructive to the leaves by feeding between the veins, sometimes the leaves were completely eaten. They were observed on the plants when the plants were four weeks old, but their numbers reduced after flowering. Similarly, the adults and nymphs of cotton stainer Dysdercus superstitious (F.) pierced and sucked sap from the leaves and fruits causing shriveling of both the leaves and pods. The cotton aphid, Aphis gossypii Glover and white fly, Bemisia tabaci (Gennadius) caused considerable damage by sucking plant sap from the undersides of leaves. Leafhoppers, Emposaca devastans (D.) occurred throughout the sampling period and caused minor damage to plant foliage by sucking sap from the undersides of the leaves. 
Table 1. Insect pests attacking okra in Legon, Ghana

\begin{tabular}{|c|c|c|c|}
\hline Name & Family & Damage & Remarks \\
\hline \multicolumn{4}{|l|}{ Coleoptera } \\
\hline Flea beetle Podagrica uniformis Jac & Chrysomelidae & Feed on leaves & Major \\
\hline Epilachna beetle Epilachna similis (F.)* & Coccinellidae & Defoliator & Major \\
\hline Lagria beetle Lagria villosa (F.) & Lagriidae & Feed on leaves & Minor \\
\hline L. cuprina (Thoms.) & Lagriidae & Feed on leaves & Minor \\
\hline Blister beetle Mylabris temporalis (W.) & Myloidae & Flower feeder & Minor \\
\hline M. abdomnalis (Thumb) & Myloidae & Flower feeder & Minor \\
\hline M. trifasciata (Thumb) & Myloidae & Flower feeder & Minor \\
\hline Scolytid beetle Labidognatha sp. & Scolytidae & Feed on leaves & Minor \\
\hline The beetle Chellomonos lunata (F.) & Coccinellidae & Aphid feeder & Beneficial \\
\hline C. vicina muls & Coccinellidae & Aphid feeder & Beneficial \\
\hline \multicolumn{4}{|l|}{ Homoptera } \\
\hline Cotton aphid Aphis gossypii Glov. & Aphididae & Suck sap and vector & Major \\
\hline $\begin{array}{l}\text { White fly Bemisia tabaci (Genn.) } \\
\text { Heteroptera }\end{array}$ & Aleryrodidae & Suck sap and vector & Major \\
\hline Cotton stainer Dysdercus superstitious F. & Pyrrhocoridae & Suck sap & Major \\
\hline $\begin{array}{c}\text { Leafhoppers Empoasca devastans (D.) } \\
\text { Lepidoptera }\end{array}$ & Cicadellidae & Feed on leaves & Minor \\
\hline Leaf roller Sylepta derogata (F.) & Pyralidae & Defoliator & Major \\
\hline The moth Prodenia litura (F.) & Noctuidae & Defoliator & Major \\
\hline $\begin{array}{c}\text { Leafworm Spodoptera littoralis Boisd. } \\
\text { Orthoptera }\end{array}$ & Noctuidae & Defoliator & Major \\
\hline Grasshopper Zonocerus variegatus (L.) & Pyrgomorphidae & Defoliator & Major \\
\hline
\end{tabular}

Insects collected from untreated plots. ${ }^{*}$ New record on okra.

The larvae of several species of moths were observed attacking mainly the foliage of okra plants. Cotton leaf worm, Spodoptera littoralis (Boisd.) caused extensive defoliation. Cotton leaf roller, Sylepta derogata (F.) was the commonest and the most destructive lepidopteran pest found. The larvae were found congregating within a roll of leaves, which they secured with silken threads as they fed on the undersurface of leaves, sometimes covering them with webbing. The leaves were curled and rolled as they fed on the leaf margins. Prodenia litura (F.) appeared late in the growing season on mature plants and fed mainly on the upper surface of the leaves. The nymps and adults of the variegated grasshopper, Zonocerus variegatus (L.), caused extensive defoliation to okra plants.

\section{Effect of actellic, Bt and neem seed extract on insect population}

Actellic, neem extract and Bt caused a significant $(\mathrm{P}<0.05)$ reduction in the population of $P$. uniformis, A. gossypii, E. similis, S. doragata, P. litura and S. littoralis compared to untreated plants (Tables 2 and 3). For all the insects sampled actellic and neem seed extracts gave similar results.

\section{Insect damage to leaves and fruit of okra}

The insect pests of okra caused three main types of damage: leaf, flower and fruit damage. The damage caused to the leaves was, however, the most significant. The feeding activity of the insects, particularly $P$. uniformis resulted in numerous holes bored into the leaves (Table 4). Leaf damage was significantly higher on the untreated plants than Actellic, neem extract or Bt treated plants.

Table 2. Population densities of $P$. uniformis, E. similis and $A$. gossypii pests on okra treated with actellic, neem extract and $B t$ at Legon, Ghana.

\begin{tabular}{llll}
\hline \multirow{2}{*}{ Treatment } & \multicolumn{3}{c}{ Mean number of adults (+SE) } \\
\cline { 2 - 4 } & P. uniformis & E. similis & A. gosypii \\
\hline Control & $120 \pm 10.5^{\mathrm{a}}$ & $45 \pm 5.5^{\mathrm{a}}$ & $85 \pm 9.5^{\mathrm{a}}$ \\
Actellic $(2 \mathrm{ml} / \mathrm{l})$ & $10 \pm 1.5^{\mathrm{c}}$ & $5 \pm 2.5^{\mathrm{c}}$ & $10 \pm 5.5^{\mathrm{c}}$ \\
$\mathrm{Bt}(1 \mathrm{~g} / \mathrm{l})$ & $25 \pm 4.5^{\mathrm{b}}$ & $15 \pm 0.3^{\mathrm{b}}$ & $38 \pm 7.5^{\mathrm{b}}$ \\
Neem extract $(30 \mathrm{~g} / \mathrm{l})$ & $12 \pm 2.5^{\mathrm{c}}$ & $4 \pm 0.5^{\mathrm{c}}$ & $14 \pm 4.2^{\mathrm{c}}$ \\
Neem extract $(50 \mathrm{~g} / \mathrm{l})$ & $12 \pm 2.5^{\mathrm{c}}$ & $3 \pm 0.4^{\mathrm{c}}$ & $11 \pm 3.8^{\mathrm{c}}$ \\
Neem extract $(75 \mathrm{~g} / \mathrm{l})$ & $10 \pm 2.2^{\mathrm{c}}$ & $3 \pm 0.5^{\mathrm{c}}$ & $10 \pm 3.5^{\mathrm{c}}$ \\
Neem seed extract $(100 \mathrm{~g} / \mathrm{l})$ & $10 \pm 2.5^{\mathrm{c}}$ & $3 \pm 0.3^{\mathrm{c}}$ & $8 \pm 1.5^{\mathrm{c}}$ \\
\hline
\end{tabular}

Note: Means for each species followed by different letter (s) are significantly different at $\mathrm{P}<0.05$, LSD

Table 3. Effect of actellic, neem extract and Bt on the larval population of Lepidopteran pests recorded on okra at Legon, Ghana.

\begin{tabular}{llll}
\hline \multirow{2}{*}{ Treatment } & \multicolumn{3}{c}{ Mean number of larvae (+SE) } \\
\cline { 2 - 4 } & S. derogata & P. litura & S. littoralis \\
\hline Control & $50 \pm 7.5^{\mathrm{a}}$ & $30 \pm 5.5^{\mathrm{a}}$ & $34 \pm 9.5^{\mathrm{a}}$ \\
Actellic $(2 \mathrm{ml} / \mathrm{l})$ & $5 \pm 1.5^{\mathrm{c}}$ & $3 \pm 2.5^{\mathrm{c}}$ & $5 \pm 0.6^{\mathrm{c}}$ \\
Bt $(1 \mathrm{~g} / \mathrm{l})$ & $15 \pm 4^{\mathrm{b}}$ & $14 \pm 0.3^{\mathrm{b}}$ & $12 \pm 5.5^{\mathrm{b}}$ \\
Neem extract $(30 \mathrm{~g} / \mathrm{l})$ & $5 \pm 0.5^{\mathrm{c}}$ & $4 \pm 0.5^{\mathrm{c}}$ & $5 \pm 0.5^{\mathrm{c}}$ \\
Neem extract $(50 \mathrm{~g} / \mathrm{l})$ & $4 \pm 0.5^{\mathrm{c}}$ & $4 \pm 0.4^{\mathrm{c}}$ & $4 \pm 0.5^{\mathrm{c}}$ \\
Neem extract $(75 \mathrm{~g} / \mathrm{l})$ & $3 \pm 0.3^{\mathrm{c}}$ & $3 \pm 0.5^{\mathrm{c}}$ & $3 \pm 0.3^{\mathrm{c}}$ \\
Neem seed extract $(100 \mathrm{~g} / 1)$ & $3 \pm 0.5^{\mathrm{c}}$ & $3 \pm 0.3^{\mathrm{c}}$ & $3 \pm 0.3^{\mathrm{c}}$ \\
\hline
\end{tabular}

Note: The same as in Table 2. 
Table 4. Effect of actellic, neem extract and Bt on levels of damage caused by the various insect pests and yield of okra.

\begin{tabular}{llccc}
\hline \multicolumn{1}{c}{ Treatment } & \multicolumn{1}{c}{$\begin{array}{c}\text { Mean no. of } \\
\text { holes per leaf }\end{array}$} & $\begin{array}{c}\text { Leaf damage } \\
(\%)\end{array}$ & $\begin{array}{c}\text { Fruit damage } \\
(\%)\end{array}$ & $\begin{array}{c}\text { Fruit weight } \\
(\mathrm{kg} / \mathrm{ha})\end{array}$ \\
\hline Control & $60 \pm 6.5^{\mathrm{a}}$ & $77 \pm 8.5^{\mathrm{a}}$ & $46 \pm 5.5^{\mathrm{a}}$ & $895 \pm 13.5^{\mathrm{a}}$ \\
Actellic $(2 \mathrm{ml} / \mathrm{l})$ & $12 \pm 15^{\mathrm{c}}$ & $11 \pm 2.5^{\mathrm{c}}$ & $2 \pm 0.2^{\mathrm{c}}$ & $4317 \pm 12.5^{\mathrm{d}}$ \\
Bt $(1 \mathrm{~g} / \mathrm{l})$ & $29 \pm 4.5^{\mathrm{b}}$ & $25 \pm 6.3^{\mathrm{b}}$ & $8 \pm 1.5^{\mathrm{b}}$ & $3886 \pm 16.2^{\mathrm{b}}$ \\
Neem extract $(30 \mathrm{~g} / \mathrm{l})$ & $18 \pm 25^{\mathrm{c}}$ & $15 \pm 2.5^{\mathrm{c}}$ & $5 \pm 0.5^{\mathrm{c}}$ & $4037 \pm 14.5^{\mathrm{c}}$ \\
Neem extract $(50 \mathrm{~g} / \mathrm{l})$ & $15 \pm 2.5^{\mathrm{c}}$ & $13 \pm 1.4^{\mathrm{c}}$ & $3 \pm 0.5^{\mathrm{c}}$ & $4437 \pm 12.4^{\mathrm{d}}$ \\
Neem extract $(75 \mathrm{~g} / \mathrm{l})$ & $15 \pm 2.2^{\mathrm{c}}$ & $11 \pm 2.5^{\mathrm{c}}$ & $3 \pm 0.6^{\mathrm{c}}$ & $4492 \pm 13.0^{\mathrm{d}}$ \\
Neem seed extract $(100 \mathrm{~g} / \mathrm{l})$ & $13 \pm 2.5^{\mathrm{c}}$ & $11 \pm 2.3^{\mathrm{c}}$ & $2 \pm 0.4^{\mathrm{c}}$ & $4389 \pm 14.0^{\mathrm{d}}$ \\
\hline
\end{tabular}

Means for each treatment followed by different letter (s) are significantly different at $\mathrm{P}<0.05$, LSD.

Actellic and neem seed extracts were equally effective in reducing insect damage to the leaves (Table 4). The feeding activity of the insects on the fruit significantly reduced their quality and marketability. The fruit of plants treated with Actellic, neem seed extracts or Bt were less damaged compared to those of the untreated plants.

\section{Fruit yield}

Actellic, neem extract and Bt had significant effect on the fruit yield of okra compared to the untreated (Table 4). Plants treated with $75 \mathrm{~g} / 1$ of neem seed extract produced the highest yield but it was not significantly different from plants treated with neem extracts at the rate of 50 and $100 \mathrm{~g} / 1$ or actellic.

\section{DISCUSSION}

The present study has confirmed that the feeding activities of leaf beetles, caterpillars and aphis cause serious damage to the leaves and fruit of okra plants and reduce yield of marketable fruits. The damage caused to the leaves was, however, the most significant. In particular $P$. uniformis bored numerous holes into the leaves and the larvae of $S$. derogata, P. litura and S. littoralis also caused extensive damage to the leaves of untreated plants. The feeding activity of the larvae and/or the adults of these pests on the leaves might have reduced the photosynthetic capacity of the plants resulting in stunted growth and low yield. E. similis is known to be a pest of cabbage and was found to feed on the leaves of the crop (Ankrah, 1998). It also attacks garden egg and other crops such as tomato, cowpea and French beans (Forsyth, 1966). Amuh (1972) recorded E. similis as a minor pest of cotton in Southern Ghana. This is the first record of its occurrence on okra in Ghana.

This study has also demonstrated the efficacy of actellic, neem extracts and Bt against major insect pests of okra in Ghana. These products caused significant reduction in the numbers of insect pests collected on treated plants. Leaf and fruit damage was, therefore, significantly higher on the untreated plants than Actellic, neem extract or Bt treated plants. It is significant to note that as much as $46 \%$ fruit damage was recorded on fruit harvested from untreated plants compared to less than $3 \%$ on neem-treated plants. This suggests promising potential for the use of neem products and Bt to manage pests of okra in Ghana. It is encouraging that many farmers are rapidly adopting the use of crude neem extracts in a variety of crop production systems in Ghana including cereals, legumes and vegetables.

The ability of neem extracts to control economically important pests of okra is of considerable interest. Though the principally active ingredient (Azadirachtin) is known to be present in only small amounts in crude extracts, the neem tree is locally available throughout Ghana. The development of suitable formulations coupled with proper collection and storage techniques might enhance the performance of neem for the control of pests of okra and other economically important crop pests.

Several workers have demonstrated the efficacy of neem products and Bt against pests of major crops in the tropics (Schmutterer, 1985; Cobbina and Osei-Owusu, 1988; Adu-Acheampong, 1997; Ankrah, 1998; Owusu-Ansah, 1999; Youdeowei, 2000; Obeng-Ofori and Kelly, 2000). Neem products have insecticidal, repellent, antifeedant, sterilising and growth inhibition effects against several species of insects (Schmutterer, 1990). Clearly the potential for the use of neem extracts and Bt in crop production is extremely high and farmer education and training on the economic and environmental benefits of these products need to be intensified. Refinement of aqueous neem extracts to standardize the most effective dosage applications for different pests and crop production systems should receive urgent attention. 
Furthermore, the accurate evaluation of the use of biopesticides in integrated pest and crop management and the sustainability of their use in smallholder crop production systems need to be further explored.

\section{ACKNOWLEDGEMENTS}

We thank I. Ofori for statistical advice and E. Owusu for very useful comments. The staff of the University farm helped in diverse ways and we are most grateful to them. Financial assistance for the project was provided by the Crop Science Department, University of Ghana, Legon.

\section{REFERENCES}

1. Adu-Acheampong, R. (1997). Laboratory and field evaluation of neem Azadirachta indica A. Juss for the management of cocoa mirids (Heteroptera: Miridae). Master of Philosophy thesis, ARPPIS Insect Science Programme, University of Ghana, Legon, 66 pp.

2. Amuh, Y.K.A. (1972). Survey of cotton pests in Southern Ghana. Ghana Journal of Science 12(2):9-39.

3. Ankrah, D.A. (1998). Efficacy of neem extract for the management of pests of cabbage Brassica oleracea var capitata L.). Bachelor of Science in Agriculture dissertation, Crop Science departrment, Faculty of Agriculture, University of Ghana, Legon 27 pp.

4. Butani, D.K. and Verms, S. (1976). Insect pests of vegetables and their control: Lady finger. Pesticides 10(7):31-37.

5. Cobbina, J. and Osei-Owusu, A. (1988). Effect of neem extracts on insect pests of egg plant, okra and cowpea. Insect Science and Its Applications 9:601609.

6. David, A.L. (1964). Insecticidal control of Bhandi (okra) leaf-hopper Empoasca devastans (D.). Madrass Agricultural Journal 51:21-23.

7. Forsyth, J. (1966). Agricultural insect pests of Ghana. Ghana University Press, Accra, 34 pp.

8. Garcia, R. and Goldberg, L.J. (1977). Studies on the toxic effect of the bacterial spore ONR 60A on non-target organisms. Annual Report of the University of California, Mosquito Control Research, $29 \mathrm{pp}$.

9. Golob, P. and Webley, D.J. (1980). The use of plants and minerals as traditional protectants of stored products. Report of Tropical Institute, UK 138 pp.
10. Hall, I.M., Arakawa, K.Y., Dulmage, H.T. and Correa, J.A. (1977). The pathogenicity of strains of $B$. thuringiesis to larvae of Aedes and Culex mosquitoes. Mosquito News 37:246-251.

11. Murthy, D.V. (1959). Control of ants Solnospsis germinator (F.) on vegetable crops. Mysore Agricultural Journal 34:9-14.

12. Norman, J.C. (1992). Tropical Vegetable Crops. Arthur H. Stockwell Limited. $252 \mathrm{pp}$.

13. Obeng-Ofori, D. and Akuamoah, R.K. (1998). An overview of neem tree research in Ghana. In: Proceedings International Seminar on the Potential of the Neem Tree in Ghana, October 27-30, 1998, pp 33-37. Dodowa, Ghana.

14. Obeng-Ofori, D. and Kelly, M.P. (2000). Managing pests of French bean Phaseolus vulgaris (L.) with a non-synthetic insecticide. Journal of the Ghana Science Association 2 (3):209-217.

15. Owusu-Ansah, F. (1999). Evaluation of neem seed water extract, Biobit and Karate on insect abundance and yield of local garden egg Solanum intergrifolium. Master of Philosophy thesis, ARPPIS Insect Science Programme, University of Ghana, Legon, 105 pp.

16. Oyolu, C. (1977). Variability in photo-period response in okra. Acta Horticulture 53:201-215.

17. Purseglove, J.W. (1972). Tropical Crops. Monocots. Longman Scientific and Technical, 607 pp.

18. Schmutterer, H. (1969). Review of crops and their pests in Sudan. In: Pests of Crops in Northern and Central Africa. Sustow Fisher Verlag, Stuttgart, Portland, $296 \mathrm{pp}$.

19. Schmutterer, H. (1985). Which insect pests can be controlled by application of neem kernel extracts under field conditions? Journal of Applied Entomology 100:468-475.

20. Schmutterer, H. (1990). Properties and potential of natural pesticides from the neem tree Azadirachta indica A. Juss. Annual Review of Entomology 89:179-188.

21. Sinnadurai, S. (1992). Vegetable Cultivation. Asempa Publishers Accra, 208 pp.

22. Spivey, C.D., Woodard, E.O. and Woodard, W.D. (1957). The production of okra in southern Georgia. Georgia Agricultural Experimental Station Bulletin, pp. 44-45.

23. Youdeowei, A. (2000). Using neem products for the management of crop pests in farmer field schools: Experiences from Ghana National IPM Programme. In: Efficacy and Commercialisation of neem products, pp. 41-44, (Brimah, A.K., ed.) GTZ, Accra, Ghana. 